ORIGINAL ARTICLE

\title{
Acaricidal activity of extracts from different structures of Piper tuberculatum against larvae and adults of Rhipicephalus microplus
}

\author{
Andrina Guimarães Silva BRAGA ${ }^{1}$, Krishna Ferri Alencar de SOUZA², Fabio da Silva BARBIERI ${ }^{3}$, \\ Cleberson de Freitas FERNANDES ${ }^{4}$, Rodrigo Barros ROCHA², José Roberto VIEIRA JUNIOR², \\ Clariana Lins LACERDA², Caroline Oliveira CELESTINO², Valdir Alves FACUNDO5, \\ Luciana Gatto BRITO3
}

\author{
Universidade Federal do Amazonas, Programa de Pós-Graduação em Biodiversidade e Biotecnologia (BioNorte), Setor Sul, Bloco M, Av. Gal. Rodrigo Otávio Jordão \\ Ramos 3000, CEP 69077-000 Manaus, Amazonas, Brasil \\ 2 Embrapa Rondônia, Rodovia BR-364, Km 5,5, Zona Rural, Caixa Postal 127, CEP 76815-800 Porto Velho, Rondônia, Brasil \\ 3 Embrapa Amazônia Oriental, Trav. Dr. Enéas Pinheiro, s/n, Bairro Marco, Caixa postal 48, CEP 66095-903 Belém, Pará, Brasil \\ ${ }^{4}$ Embrapa Agroindústria Tropical, Rua Dra. Sara Mesquita 2270, Bairro Planalto do Pici, CEP 60511-110 Fortaleza, Ceará, Brasil \\ Universidade Federal de Rondônia, BR-364, Km 9,5, CEP 76801-059 Porto Velho, Rondônia, Brasil \\ * Corresponding author: fabio.barbieri@embrapa.br
}

\begin{abstract}
The strategies to control the cattle tick, Rhipicephalus microplus are based mainly on the use of synthetic pesticides. However, the emergence, establishment, and development of resistance of ticks is rendering the main chemical groups ineffective. Finding new molecules to effectively control infestations by $R$. microplus is necessary to maintain the productivity of cattle herds, particularly of taurine breeds established in equatorial and tropical regions of the world. Ethanol extracts from the leaves, stems, and fruits of Piper tuberculatum were evaluated in bioassays at concentrations of 50,25, 12.50, 6.25, 3.12 and $1.56 \mathrm{mg} \mathrm{mL}^{-1}$. The concentrations lethal to $50 \%$ of the individuals $\left(\mathrm{LC}_{50}\right)$ of tick larvae after 24 hours of exposure were 3.62 , 3.99 and $5.30 \mathrm{mg} \mathrm{mL}^{-1}$ for fruit, stem and leaf extracts, respectively. Against the engorged females, the highest efficacy rates were obtained at the concentration of $50 \mathrm{mg} \mathrm{mL}^{-1}$, corresponding to $71.57 \%, 68.38 \%$ and $37.03 \%$ of the fruit, leaf and stem extracts, respectively. The main effect of the ethanol extracts was on the egg hatching rate of ticks, with a reduction of $55.63 \%$ for the fruit and leaf extracts, and $20.82 \%$ for the stem extract. The results show that $P$. tuberculatum is a promising source of molecules for use as active ingredients in pesticide formulations for $R$. microplus control.
\end{abstract}

KEYWORDS: cattle tick, bioassay, active molecules, Piperaceae

\section{Atividade acaricida de extratos de diferentes estruturas de Piper tuberculatum sobre larvas e adultos de Rhipicephalus microplus}

\section{RESUMO}

Estratégias de controle do carrapato dos bovinos, Rhipicephalus microplus, fundamentam-se na utilizaçáo de pesticidas. Os principais grupos químicos utilizados atualmente mostram-se ineficazes devido ao surgimento de populaçóes resistentes. A pesquisa de novas moléculas com eficiência acaricida é uma necessidade para manutençáo da produtividade dos rebanhos bovinos estabelecidos em regióes de clima tropical. Avaliamos a atividade de Piper tuberculatum para o controle de fêmeas ingurgitadas e larvas de $R$. microplus através de bioensaios de imersão de adultos e de pacotes de larvas. As concentraçôes avaliadas foram de 50; 25; 12,50; 6,25; 3,12 e 1,56 $\mathrm{mg} \mathrm{mL}^{-1}$ de extrato etanólico de folha, talo e fruto de $P$. tuberculatum. As concentraçóes letais para 50\% dos indivíduos $\left(\mathrm{CL}_{50}\right)$ após 24 horas de exposição de larvas de $R$. microplus foram 3,62; 3,99 e 5,30 mg mL para os extratos etanólicos de fruto, talo e folha, respectivamente. Para fêmeas ingurgitadas, a maior eficácia resultou da concentraçấo de $50 \mathrm{mg} \mathrm{mL}^{-1}$ de extrato de fruto $(71.57 \%)$. O principal efeito dos extratos etanólicos de $P$. tuberculatum foi sobre a eclodibilidade, com uma redução de $55.63 \%$ para extratos de fruto e folha. P. tuberculatum mostra-se promissora como fonte de moléculas candidatas a uso em pesticidas, em formulaçôes destinadas ao controle das infestaçôes de $R$. microplus.

PALAVRAS-CHAVE: carrapato dos bovinos, bioensaios, biomoléculas ativas, Piperaceae

CITE AS: Braga, A.G.S.; Souza, K.F.A.; Barbieri, F.S.; Fernandes, C.F.; Rocha, R.B.; Vieira Junior, J.R.; Lacerda, C.L.; Celestino, C.O.; Facundo, V.A.; Brito, L.G. 2018. Acaricidal activity of extracts from different structures of Piper tuberculatum against larvae and adults of Rhipicephalus microplus. Acta Amazonica 48: 57-62. 


\section{INTRODUCTION}

The global economic losses to cattle breeders caused by pests due to lower milk and meat production, hide damage and treatment costs are enormous. The latest data indicate that in Brazil alone, these losses amount to US\$ 6 billion a year, of which $50 \%$ are attributed to the cattle tick, Rhipicephalus microplus (Canes.) (Grisi et al. 2014).

The primary method used to minimize these losses is the application of synthetic pesticides. However, the incorrect and indiscriminate use of these products has caused the development of cattle tick populations that are resistant to the various commercially available chemical groups (Brito et al. 2011). The search for new molecules with acaricidal activity is currently one of the greatest challenges to maintaining the sustainability of cattle breeding in tropical regions.

The promising biocidal activity of various plants to control different pathogenic vectors and agents that impair livestock and human health has been demonstrated by various studies (Klauck et al. 2014; Custódio et al. 2016; Rodrigues et al. 2017; Fatemi et al. 2017). The active research interest in the chemical components produced by the metabolism of plants has led to the isolation of various substances that take part in the defense mechanisms of plants against attack by pests and diseases. Among these substances, alkaloids, steroids, terpenes, phenylpropanoids, lignans, flavonoids, and amides stand out as promising bioactive molecules from plants for use in the health sciences (Parmar et al. 1997).

Approximately 55 plant species have been evaluated regarding their potential use to control $R$. microplus (Borges et al. 2011),. Among these, Piper tuberculatum Jacq. (Piperaceae), popularly known in Brazil as "pimenta d'arda" or "pimenta longa", stands out as a promising species that produces bioactive molecules with potential use to control pests and diseases that affect both crops (Scott et al. 2002; Castro et al. 2008; Trindade et al. 2012) and livestock (Chagas et al. 2012; Lima et al. 2014). Extracts of P. tuberculatum also have proven action against protozoa of medical importance such as Leishmania amazonensis (Ferreira et al. 2010) and Trypanossoma cruzi (Regasini et al. 2009). It also has molluscicidal effect against Biomphalaria glabrata, the intermediate host of Schistosoma mansoni (Rapado et al. 2011; Rapado et al. 2013).

This study involved the testing of ethanol extracts of the leaves, stems, and fruits of $P$. tuberculatum for control of $R$. microplus, to determine what structures of this plant have stronger acaricidal activity and can thus be used as a source to synthesize new active ingredients and a bioactive product for control of cattle tick populations. The evaluations were performed through the bioassays: 1) Adult Immersion Test (TIA) for engorged females; and 2) Larval Packet Test (LPT) for the larval stage.

\section{MATERIAL AND METHODS}

\section{Collection of the plant material}

Leaves, stems, and fruits of Piper tuberculatum were collected in the native forest reserve area of the Federal University of Rondônia (6356 $22^{\prime \prime} \mathrm{W}, 8^{\circ} 50^{\prime} 03^{\prime \prime}$ ) ), in the municipality of Porto Velho, state of Rondônia (southwestern Amazon) in January 2013. Prepared botanical vouchers were sent to the Herbarium of the National Research Institute of the Amazon (INPA) for identification confirmation, and registered under number 211724.

\section{Extract preparation and dilution}

Leaves $(1.40 \mathrm{~kg})$, stems $(1.60 \mathrm{~kg})$ and fruits $(0.30 \mathrm{~kg})$ were submitted to extraction with ethanol PA (3 L) for seven days, to obtain extracts from leaves (PTLEt, $87 \mathrm{~g}$ ), stems (PTSEt, 36 g) and fruits (PTFEt, $46.90 \mathrm{~g}$ ). For the bioassays, the solutions of the three ethanol extracts of $P$. tuberculatum were diluted in ethanol (larval packet test) and water + Tween 20 at 2\% (adult immersion test). The gross extracts were weighed and diluted in the solvents with the aid of ultrasound and a vortex agitator to maximize the solubilization. The final concentrations of 50 , $25,12.50,6.25,3.12$ and $1.56 \mathrm{mg} \mathrm{mL}^{-1}$ were obtained after dissolving the crude extract. The extracts at a concentration higher than $50 \mathrm{mg} \mathrm{mL}^{-1}$ had high density and viscosity, so they were not evaluated.

\section{Tick preparation and bioassays}

Engorged females were collected from naturally infested cattle maintained at the Experimental Field of Porto Velho of Embrapa Rondônia (6350'58”W, 848'10”S). Immediately after collection, the ticks were immersed in a $2 \%$ sodium hypochlorite solution, dried on paper towels and selected according to integrity, motility, and degree of engorgement.

The larvae used in the larval packet test (LPT) came from 30 engorged females. These ticks were attached dorsally with two-sided tape in Petri dishes and placed in a BOD chamber at a temperature of $27+/-1^{\circ} \mathrm{C}$ and relative humidity above $80 \%$ for egg laying. After 18 days of oviposition, the egg masses were removed and placed in plastic tubes plugged with hydrophilic cotton and kept in the BOD chamber under the same temperature and humidity conditions previously described, until hatching of the larvae. Bioassays were conducted in triplicate for each concentration of the extracts, both in larval and engorged female tests.

\section{Larvae sensitivity on impregnated paper}

The bioassays to assess the efficiency of the extract on $R$. microplus larvae were performed according to Stone and Haydock (1962), as modified by Miller et al. (2002). The packets were made of filter paper and impregnated with each concentration of the stem, leaf and fruit extracts diluted in alcohol. As controls, packets were impregnated with ethanol 
(negative control) and technical grade cypermethrin diluted in acetone at a concentration of $25.60 \mu \mathrm{g} \mathrm{mL}-1$ (positive control).

Approximately 100 larvae were placed in each packet, which was immediately sealed with paper clips and put in the BOD chamber at a temperature of $27+/-1^{\circ} \mathrm{C}$ and humidity greater than $80 \%$, where they remained for 2 hours. After this interval, the packets were opened, and the living and dead larvae were counted in each replicate to calculate mortality.

\section{Immersion test with engorged females}

The acaricidal potential of the stem, leaf and fruit extracts of $P$. tuberculatum on engorged females was analyzed by the adult immersion test (AIT), as described by Drummond et al. (1973). Each replicate consisted of a group of ten females, with homogeneous weight, immersed for five minutes in $10 \mathrm{ml}$ of extract at each of the concentrations evaluated. As controls we used technical grade cypermethrin diluted in acetone at a concentration of $25.60 \mu \mathrm{g} \mathrm{mL}^{-1}$ (positive control) and water + Tween 20 at $2 \%$ (negative control). After immersion, the engorged females were dried on a paper towel and mounted dorsally in Petri dishes with two-sided tape. The plates were kept in the BOD chamber at a temperature of $27+/-1^{\circ} \mathrm{C}$ and humidity above $80 \%$.

After the end of oviposition, the egg masses of each group were weighed and allocated in labeled plastic syringes plugged with cotton and incubated in the BOD under the same temperature and humidity conditions as described previously for larval hatching. The number of hatched and not hatched eggs were counted after 16 days to determine the percentage reduction of oviposition (\% OR) and hatching (\% HR) (Gonzales 2003). Estimated reproduction (ER), and treatment efficacy (E) were calculated according to Drummond et al. (1973) as follows:

\section{Statistical analysis}

The 50\% lethal concentration (LC50) was calculated for larvae using packet test mortality data in regression analysis using the Probit test, performed with the BioStat 2009 Professional 5.8.4 software. Variables from the adult immersion test were analyzed using ANOVA with a factorial design of $6 \times 3$ (concentration $x$ extracts) followed by the Scott and Knott's test at 5\% significance level using the GENES Program (Cruz, 2016).

\section{RESULTS}

The leaf and stem extracts caused $100 \%$ mortality of the larvae starting at the concentration of $12.50 \mathrm{mg} \mathrm{mL}^{-1}$, while the fruit extract achieved maximum mortality of $96.20 \%$ only at the concentration of $50 \mathrm{mg} \mathrm{mL}^{-1}$ (Figure 1). Although the fruit extract did not produce $100 \%$ mortality, at the lowest concentrations it performed better than the leaf and stem extracts. The fruit extract also had the lowest $\mathrm{LC}_{50}$ value, 3.62 $\pm 2.21(0.73-17.98) \mathrm{mg} \mathrm{mL}^{-1}$ (Table 1$)$. The mortality of the negative control was below $5 \%$ and of the positive control above $90 \%$ demonstrating the quality of the test.

No significant differences of percentage reduction of oviposition were observed in relation to the concentration among the three extracts. A significant difference was only observed for the average percentage reduction of oviposition caused by the PTLEt at concentrations of 3.12 e $1.56 \mathrm{mg}$ $\mathrm{mL}^{-1}$ when compared to the other concentrations (Table 2).

With respect to the percentage reduction of hatching, the comparison of the averages for the extracts PTLEt, PTSEt and PTFEt revealed a significant difference among the concentrations of $1.56,6.25$ and $12.50 \mathrm{mg} \mathrm{mL}^{-1}$ for the three extracts, where the highest averages for these

\section{a PTLEt $\square$ PTSEt $\square$ PTFEt}

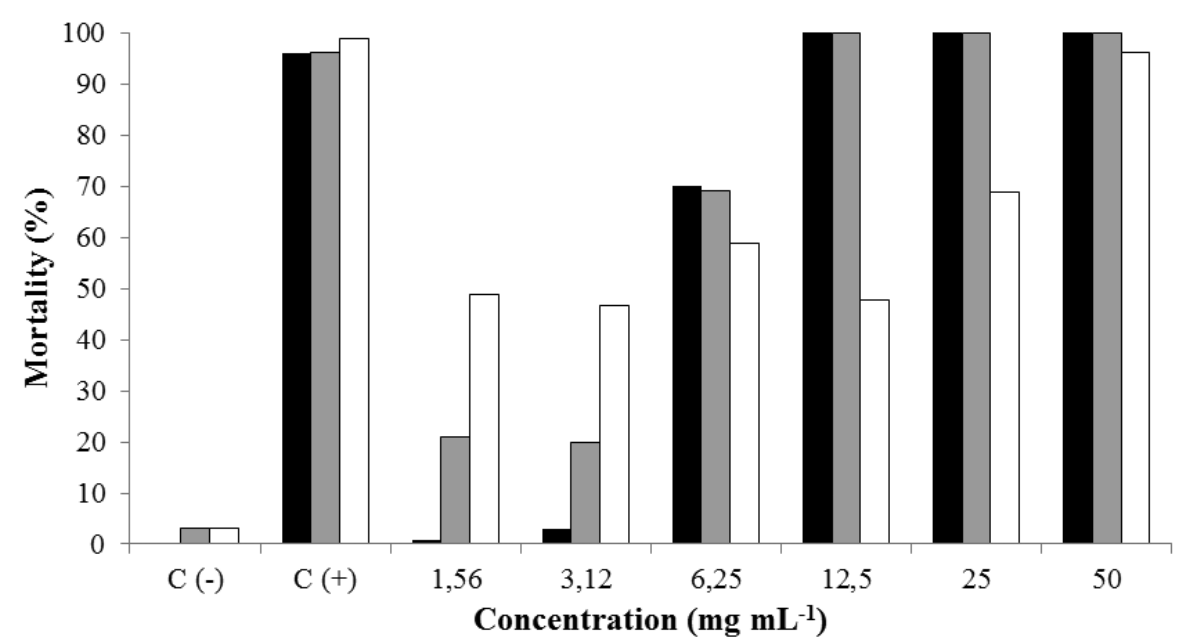

Figure 1. Mortality of Rhipicephalus microplus larvae in ethanol extracts of the leaf (PTLEt), stem (PTSEt) and fruit (PTFEt) of Piper tuberculatum in the larval packet test. Negative control is represented by C (-) and positive control by C (+). 
concentrations were observed for PTFEt. For all the extracts, the highest percentages reduction of hatching occurred at the concentration of $50 \mathrm{mg} \mathrm{mL}^{-1}$. For PTFEt, the concentrations of 6.25 and $12.50 \mathrm{mg} \mathrm{mL}^{-1}$ caused the same reduction (the greatest hatching reduction for this extract) (Table 2).

Table 1. $L C_{50}(50 \%$ lethal concentration) of the ethanol extracts of the leaf (PTLEt), stem (PTSEt) and fruit (PTFEt) of Piper tuberculatum on larvae of Rhipicephalus microplus. Values are means of three replicates followed by the standard deviation and the range.

\begin{tabular}{lc}
\hline Extract & $\mathrm{LC}_{50}\left(\mathrm{mg} \mathrm{mL}^{-1}\right)$ \\
\hline PTLEt & $5.30 \pm 0.84(3.42-8.21)$ \\
PTSEt & $3.99 \pm 0.80(2.18-6.60)$ \\
PTFEt & $3.62 \pm 2.21(0.73-17.98)$ \\
\hline
\end{tabular}

Table 2. Average percentage reduction oviposition (\%OR), hatching reduction percentages (\%HR), estimated reproduction (ER), and efficacy (E) in the adult immersion test (AIT) with ethanol extracts of leaf (PTLEt), stem (PTSEt) and fruit (PTFEt) of Piper tuberculatum on engorged Rhipicephalus microplus females. Concentration (Conc.) in $\mathrm{mg} \mathrm{mL}^{-1}$. Numbers are means followed by the standard deviation. Equal upper-case letters in the row and lower-case letters in the column indicate no difference by the Scott-Knott test at 5\% significance level.

\begin{tabular}{|c|c|c|c|c|}
\hline & Conc. & PTLEt & PTSEt & PTFEt \\
\hline \multirow{6}{*}{$\% O R$} & 50 & $35.01 \pm 16.20^{\mathrm{Aa}}$ & $26.04 \pm 4.98^{\mathrm{Aa}}$ & $31.91 \pm 7.03^{\mathrm{Aa}}$ \\
\hline & 25 & $30.38 \pm 3.71^{\text {Aa }}$ & $27.33 \pm 7.09^{\mathrm{Aa}}$ & $14.72 \pm 7.71^{\text {Aa }}$ \\
\hline & 12.5 & $32.05 \pm 3.71^{\text {Aa }}$ & $27.89 \pm 11.40^{\mathrm{Aa}}$ & $29.49 \pm 6.03^{\mathrm{Aa}}$ \\
\hline & 6.25 & $27.53 \pm 9.36^{\mathrm{Aa}}$ & $20.56 \pm 8.09^{\mathrm{Aa}}$ & $23.87 \pm 2.79^{\text {Aa }}$ \\
\hline & 3.12 & $14.36 \pm 3.35^{\mathrm{Ab}}$ & $26.27 \pm 8.62^{\mathrm{Aa}}$ & $20.92 \pm 12.44^{\mathrm{Aa}}$ \\
\hline & 1.56 & $13.27 \pm 9.30^{\mathrm{Ab}}$ & $11.38 \pm 6.33^{\mathrm{Aa}}$ & $20.50 \pm 12.25^{\text {Aa }}$ \\
\hline \multirow{6}{*}{$\% \mathrm{HR}$} & 50 & $55.63 \pm 12.88^{\mathrm{Aa}}$ & $20.82 \pm 5.15^{\mathrm{Ba}}$ & $55.63 \pm 4.26^{\mathrm{Aa}}$ \\
\hline & 25 & $44.37 \pm 6.17^{\mathrm{Ab}}$ & $14.68 \pm 4.26^{\mathrm{Ba}}$ & $38.57 \pm 7.38^{\mathrm{Ab}}$ \\
\hline & 12.5 & $1.02 \pm 0.59^{c d}$ & $15.02 \pm 4.46^{\mathrm{Ba}}$ & $55.97 \pm 4.69^{\mathrm{Aa}}$ \\
\hline & 6.25 & $1.02 \pm 0.59^{c d}$ & $20.82 \pm 7.26^{\mathrm{Ba}}$ & $56.97 \pm 4.69^{\text {Аa }}$ \\
\hline & 3.12 & $21.50 \pm 2.96^{\mathrm{BC}}$ & $21.16 \pm 2.71^{\mathrm{Ba}}$ & $51.54 \pm 9.23^{\text {Аа }}$ \\
\hline & 1.56 & $18.77 \pm 5.25^{\mathrm{BC}}$ & $3.75 \pm 2.71^{\mathrm{cb}}$ & $54.61 \pm 8.59^{\text {Aa }}$ \\
\hline \multirow{6}{*}{ ER } & 50 & $16.03 \pm 8.00^{\mathrm{Bb}}$ & $31.92 \pm 3.72^{A b}$ & $14.41 \pm 2.44^{\mathrm{Bb}}$ \\
\hline & 25 & $20.29 \pm 2.93^{\mathrm{Bb}}$ & $32.97 \pm 2.63^{\mathrm{Ab}}$ & $24.09 \pm 4.14^{\mathrm{Ba}}$ \\
\hline & 12.5 & $35.26 \pm 0.76^{\mathrm{Aa}}$ & $33.16 \pm 3.46^{\mathrm{Ab}}$ & $14.45 \pm 2.41^{\mathrm{Bb}}$ \\
\hline & 6.25 & $37.85 \pm 4.80^{\mathrm{Aa}}$ & $31.61 \pm 3.93^{\mathrm{Bb}}$ & $15.22 \pm 1.65^{\mathrm{cb}}$ \\
\hline & 3.12 & $33.85 \pm 3.61^{\mathrm{Aa}}$ & $32.20 \pm 3.12^{\mathrm{Ab}}$ & $17.55 \pm 5.6^{\mathrm{Bb}}$ \\
\hline & 1.56 & $34.62 \pm 3.69^{\text {ва }}$ & $45.08 \pm 2.21^{\mathrm{Aa}}$ & $16.40 \pm 0.64^{\mathrm{cb}}$ \\
\hline \multirow{6}{*}{$E$} & 50 & $68.38 \pm 15.78^{\text {Аа }}$ & $37.03 \pm 7.34^{\mathrm{Ba}}$ & $71.57 \pm 4.80^{\mathrm{Aa}}$ \\
\hline & 25 & $59.98 \pm 5.78^{\mathrm{Aa}}$ & $34.96 \pm 5.20^{\mathrm{Ba}}$ & $52.48 \pm 8.16^{\mathrm{Ab}}$ \\
\hline & 12.5 & $30.45 \pm 1.51^{\mathrm{Bb}}$ & $34.60 \pm 6.82^{\mathrm{Ba}}$ & $71.49 \pm 4.75^{\text {Аа }}$ \\
\hline & 6.25 & $25.33 \pm 9.48^{\mathrm{cb}}$ & $37.65 \pm 7.75^{\text {ва }}$ & $69.97 \pm 3.25^{\text {Аa }}$ \\
\hline & 3.12 & $33.24 \pm 7.12^{\mathrm{Bb}}$ & $36.48 \pm 6.14^{\mathrm{Ba}}$ & $65.38 \pm 10.96^{\mathrm{Aa}}$ \\
\hline & 1.56 & $31.71 \pm 7.28^{8 b}$ & $11.07 \pm 4.36^{\mathrm{Bb}}$ & $67.64 \pm 1.26^{\mathrm{Aa}}$ \\
\hline
\end{tabular}

The average estimated reproduction measures declined significantly for the engorged females immersed in PTLEt and PTSEt. For all the extracts, the concentration of $50 \mathrm{mg} \mathrm{mL}^{-1}$ was most effective in reducing the estimated reproduction (Table 2). The concentration of $50 \mathrm{mg} \mathrm{mL}^{-1}$ of both the PTFEt and PTLEt extracts presented the best performance in the AIT, with treatment efficacy levels of $71.57 \%$ and $68.38 \%$, respectively (Table 2). There were no viable postures in the female groups of the positive control, demonstrating high pyrethroid efficacy in the evaluated population of $R$. microplus.

\section{DISCUSSION}

Leaf extracts of $P$. tuberculatum have previously been studied as insecticides (Trindade et al. 2012; Castro et al. 2008), however, very few studies have been conducted to assess the use of this plant's extracts against ticks (Chagas et al. 2012). The efficiency of an acaricide can vary according to the extraction method, solvent polarity and plant part used to obtain the extract (Lima et al. 2014).

All three extracts showed promise against the larvae of Rhipicephalus microplus. Chagas et al. (2012) observed similar results $\left(\mathrm{LC}_{50}=0.41 \% \approx 4.10 \mathrm{mg} \mathrm{mL}-1\right)$ using leaf extract of $P$. tuberculatum to control $R$. microplus larvae. Lima et al. (2014) obtained a $\mathrm{LC}_{50}$ value approximately 50 times lower than that observed in this study for the ethanol extracts from the fruit of $P$. tuberculatum, and found that extracts obtained using solvents of lower polarity were more effective. Unlike Lima et al. (2014), we found that the strongest acaricidal activity of $P$. tuberculatum was produced by the leaf extracts, which can be due to the extraction method or solvent polarity (Silva et al. 2009).

The extract from the fruits of $P$. tuberculatum was the most effective in reducing the egg hatching rate in this study, yet Chagas et al. (2012) reported a $91.66 \%$ egg reduction for a $10 \%\left(\approx 100 \mathrm{mg} \mathrm{mL}^{-1}\right)$ concentration of $P$. tuberculatum leaf extract, while at $5 \%\left(\approx 50 \mathrm{mg} \mathrm{mL}^{-1}\right)$ the efficacy was only $58.61 \%$, close to that observed in our study. The efficacy of fruit extracts of $P$. tuberculatum on $R$. microplus females was of $11.40 \%$ using ethanol as solvent, but was $100 \%$ and $96.20 \%$ using hexane and ethyl ether, respectively, all at a concentration of $75 \mathrm{mg} \mathrm{mL}^{-1}$ in the adult immersion test (Lima et al. 2014). The latter authors measured an $\mathrm{LC}_{50}$ of $2.73 \mathrm{mg} \mathrm{mL}^{-1}$ for the ethanol extract of $P$. tuberculatum fruits on $R$. microplus larvae, close to that observed in this study.

Santos et al. (2015) assessed the in vitro effect of the aqueous extract, hydroalcoholic extract, concentrated hydroalcoholic extract and essential oil of lemongrass (Cymbopogon wynterianus) on $R$. microplus larvae and engorged females. They found that the samples had acaricidal action, mainly the essential oil, because starting at a concentration of $12.50 \%$ it caused $100 \%$ larval mortality, and at $25 \%$ it had 
an efficacy index of $100 \%$ in the test with engorged females, a better result than observed in our study.

Other Piper species have been evaluated for control of $R$ microplus larvae and adults. In vitro tests showed the toxic potential of the hexane extract and essential oil of the leaves of $P$. aduncum against $R$. microplus larvae and adults (Silva $e t$ al. 2009). In an evaluation of essential oils of $P$. amalago, $P$. mikanianum and $P$. xylosteoides, the highest mortality of $R$. microplus larvae was observed for $P$. mikanianum $\left(\mathrm{LC}_{50}=2.33\right.$ $\mu \mathrm{L} \mathrm{mL}^{-1}$ ), followed by $P$. xylosteoides, while $P$. amalago showed no acaricidal activity on larvae (Ferraz et al.(2010).

A wider range of plants should be evaluated regarding their acaricidal potential against $R$. microplus larvae and engorged females. One phytochemical study indicated that $94.84 \%$ of the composition of the essential oil of $P$. aduncum consists of dillapiole (Silva et al. 2009). Another study found that the majority component of P. mikanianum essential oil is apiole (67.88\%) and of P. xylosteoides is safrol (47.83\%), while the essential oil of $P$. amalago contains $20.52 \%$ limonene (Ferraz et al. 2010). The differences in the chemical constituents isolated from different Piper species can be related to the genetic diversity of these species, as well as the foliar age of the plant, edaphoclimatic variations and different extraction methods applied (Facundo et al. 2008).

The $P$. tuberculatum extracts demonstrated acaricidal action against larvae and engorged females of $R$. microplus. However, further research is needed to obtain and identify the constituents of these extracts responsible for that action, since biomolecules appear to have great promise for use as biocides against pests and diseases that afflict plants and animals, including humans. Phytochemical studies aimed at isolating these substances, as well as in vitro tests with fractions of plant extracts and substances isolated from the metabolism of plants, should be conducted to identify new acaricidal molecules for use in the pharmaceutical industry.

\section{CONCLUSIONS}

The ethanol extracts obtained from the leaves, stems and fuits of $P$. tuberculatum presented acaricidal activity in vitro against larvae and engorged females of Rhipicephalus microplus. The fruit extract presented the best result as acaricide for larvae, followed by the extracts of stems and leaves. Against engorged females, fruit and leaf extracts presented the highest efficacy. Despite high activity against larvae, the stem extract presented low efficacy against engorged females. In general, the fruit of $P$. tuberculatum was the most promising material for the development of acaricides.

\section{ACKNOWLEDGMENTS}

We thank the Conselho Nacional de Desenvolvimento Científico e Tecnológico (CNPq - grant no. 406156/2013-
1) for financial support and research scholarships, the Fundação de Amparo ao Desenvolvimento das Açöes Científicase Tecnológicas e à Pesquisa do Estado de Rondônial Coordenaçáo de Aperfeiçoamento de Pessoal de Nível Superior (FAPERO/ CAPES) for one research scholarship, Fundação de Amparo à Pesquisa do Estado do Amazonas (FAPEAM) for one doctoral grant, and Empresa Brasileira de Pesquisa Agropecuária (Embrapa - SEG 02.14.00.004.00.00) for financial support.

\section{REFERENCES}

Brito, L.G.; Barbieri, F.S.; Rocha, R.B.; Oliveira, M.C.S.; Ribeiro, E.S. 2011. Evaluation of the Efficacy of Acaricides Used to Control the Cattle Tick, Rhipicephalus microplus, in Dairy Herds Raised in the Brazilian Southwestern Amazon. Veterinary Medicine International, 2011: ID 806093. doi:10.4061/2011/806093.

Borges, L.M.F.; Sousa, L.A.D.; Barbosa, C.S. 2011. Perspectives for the use of plant extracts to control the cattle tick Rhipicephalus (Boophilus) microplus. Brazilian Journal of Veterinary Parasitology, 20: 89-96.

Castro, M.J.P.; Silva, P.H.S.; Pádua, L.E.M. 2008. Atividade de extratos de Piper tuberculatum Jacq. (Piperaceae) sobre Shodoptera frugiperda (J.E. Smith). Revista Ciência Agronômica, 3: 437-442.

Chagas, A.C.S.; Barros, L.D.; Cotinguiba, F.; Furlan, M.; Giglioti, R., Oliveira, M.C.S.; Bizzo, H.R. 2012. In vitro efficacy of plant extracts and synthesized substances on Rhipicephalus (Boophilus) microplus (Acari: Ixodidae). Parasitology Research, 110: 295-303.

Custódio, K.M.; Oliveira, J.G.O.; Moterle, D.; Zepon, K.M.; Prophiro, J.S.; Kanis, L.A. 2016. A biodegradable device for the controlled release of Piper nigrum (Piperaceae) standardized extract to control Aedes aegypti (Diptera, Culicidae) larvae. Revista da Sociedade Brasileira de Medicina Tropical, 49: 687-692.

Cruz, C.D. 2016. Genes Software - extended and integrated with the R, Matlab and Selegen. Acta Scientiarum Agronomy (Online), 38: 547-552.

Drummond, R.O.; Ernest, S.E.; Trevino, J.L.; Gladney, W.J.; Grahan, O.H. 1973. Boophilus annulatus and Boophilus microplus: laboratory tests of insecticides. Journal of Economic Entomology, 66: 130-133.

Facundo, V.A.; Polli, A.R.; Rodrigues, R.V.; Militão, J.S.L.T.; Stabeli, R.G.; Cardoso, C.T. 2008. Constituintes químicos fixos e voláteis dos stems e fruits de Piper tuberculatum Jacq. e das raízes de Piper hispidum H. B. K. Acta Amazonica, 38: 733-742.

Fatemi, A.; Asasi, K.; Razavi, S.M. 2017. Anticoccidial effects of Artemisia annua ethanolic extract: prevention, simultaneous challenge-medication, and treatment. Parasitology Research, 116:2581-2589.

Ferraz, A.B.F.; Balbino, J.M.; Zini, C.A.; Ribeiro, V.L.; Bordignon, S.A.; Von Poser, G. 2010. Acaricidal activity and chemical composition of the essential oil from three Piper species. Parasitology Research, 10: 243-248.

Ferreira, M.G.P.R.; Kayano, A.M.; Silva-Jardim, I.; Silva, T.O.; Zuliani, J.P.; Facundo, V.A.; Calderon, L.A.; Silva, A.A.; Ciancaglini, P.; Stabeli, R.G. 2010. Antileishmanial activity of 3-(3,4,5-trimethoxyphenyl) propanoic acid purified from 
Amazonian Piper tuberculatum Jacq., Piperaceae, fruits. Revista Brasileira de Farmacognosia, 20: 1003-1006.

Gonzales, J.C. 2003. O controle do carrapato do boi. 3rd ed. Universidade de Passo Fundo, Rio Grande do Sul, 128p.

Grisi, L.; Leite, R.C.; Martins, J.R.S.; Barros, A.T.M.; Andreotti, R.; Cançado, P.H.D.; León, A.A.P.; Pereira, J.B.; Villela, H.S. 2014. Reassessment of the potential economic impact of cattle parasites in Brazil. Brazilian Journal of Veterinary Parasitology, 23: 150-156.

Klauck, V.; Pazinato, R.; Stefani, L. M.; Santos, R. C.; Vaucher, R. A.; Baldissera, M. D.; et al. 2014. Insecticidal and repellent effects of tea tree and andiroba oils on flies associated with livestock. Medical and Veterinary Entomology, 28: 33-39.

Miller, R.J.; Davey, R.B.; George, J.E. 2002. Modification of the food and agriculture organization larval packet test to measure amitraz susceptibility against ixodidae. Journal of Medical Entomology, 39: 645-651.

Lima, A.S.; Sousa Filho, J.G.N.; Pereira, S.G.; Guillon, G.M.S.P.; Santos, L.S.; Costa Júnior, L.M. 2014. Acaricide activity of different extracts from Piper tuberculatum fruits against Rhipicephalus microplus. Parasitology Research, 113: 107-112.

Parmar, V.S.; Jain, S.C.; Bisht, K.S.; Jain, R.; Taneja, P.; Jha, A.; Tyagi, O.D.; Prasad, A.K.; Wengel, J.; Olsen, C.E.; Boll, P.M. 1997. Phytochemistry of the genus Piper. Phytochemistry, 46: 597-673.

Rapado, L.N.; Nakano, E.; Ohlweiler, F.P.; Kato, M.J.; Yamaguchi, L.F.; Pereira, C.A.B.; Kawano, T. 2011. Molluscicidal and ovicidal activities of plant extracts of the Piperaceae on Biomphalaria glabrata (Say, 1818). Journal of Helminthology, 85: 66-72.

Rapado, L.N.; Lopes, P.O.M.; Yamaguchi, L.F.; Nakano, E. 2013. Ovicidal effect of Piperaceae species on Biomphalaria glabrata, Schistosoma mansoni host. Revista do Instituto de Medicina Tropical de São Paulo, 55: 421-424.

Regasini, L.O.; Cotinguiba, F.; Passerini, G.D.; Bolzani, V.S.; Cicarelli, R.M.B.; Kato, M.J.; Furlan, M. 2009. Trypanocidal activity of Piper arboreum and Piper tuberculatum (Piperaceae). Revista Brasileira de Farmacognosia, 19: 199-203.
Rodrigues, D.F.; Maniscalco, D.A.; Silva, F.A.J.; Chiari, B.G.; Castelli, M.V.; Isaac, V.L.B.; Cicarelli, R.M.B.; López, S.N. 2017. Trypanocidal Activity of Flavokawin B, a Component of Polygonum ferrugineum Wedd. Planta Medica, 83: 239-244.

Santos, T.R.B.; Castro, N.A.; Bretanha, L.C.; Schuch, L.F.D.; Freitas, R.A.; Nizoli, L.Q. 2015. Estudo in vitro da eficácia de citronela (Cymbopogon wynterianus) sobre o carrapato Rhipicephalus (Boophilus) microplus. Science and Animal Health, 3: 135-149.

Scott, I.M.; Puniani, E.; Durst, T.; Phelps, D.; Merali, S.; Assabgui, R.A.; Sánchez-Vindast, P.; Poveda, L.; Philogène, B.J.R.; Arnason, J.T. 2002. Insecticidal activity of Piper tuberculatum Jacq. extracts: synergistic interation of piperamides. Agricultural and Forest Entomology, 4: 137-144.

Silva, W.C.; Martins, J.R.S.; Souza, H.E.M.; Heinzen, H.; Cesio, M.V.; Mato, M.; Albrecht, F.; Azevedo, J.L.; Barros, N.M. 2009. Toxicity of Piper aduncum L. (Piperales: Piperaceae) from the amazon forest for the cattle tick Rhipicephalus (Boophilus) microplus (Acari: Ixodidae). Veterinary Parasitology, 164: 267-274

Stone, B.F.; Haydoc, K.P. 1962. A method for measuring the acaricide susceptibility of the cattle tick Boophilus microplus (Can.). Bulletin of entomological research, 53: 563-578.

Trindade, F.T.T.; Stabeli, R.G.; Facundo, V.A.; Cardoso, C.T.; Silva, M.A.; Gil, L.H.S.; Silva-Jardim, I.; Silva, M.A. 2012. Evaluation of larvicidal activity of the methanolic extracts of Piper alatabaccum branches and $P$. tuberculatum leaves and compounds isolated against Anopheles darlingi. Revista Brasileira de Farmacognosia, 22: 979-984.

RECEIVED: 05/01/2017

ACCEPTED: $30 / 08 / 2017$

ASSOCIATE EDITOR: João Vicente Braga Souza 